\title{
Effect of frozen storage on the biochemical, microbial and sensory attributes of Skipjack Tuna (Katsuwonus pelamis) fish loins
}

\author{
Suprakash Chakma ${ }^{1 *}$, Susmita Saha ${ }^{2}$, Nazmul Hossain ${ }^{3}$, Md. Arifur Rahman ${ }^{4}$, Marjan Akter ${ }^{5}$, Md. Sazedul Hoque ${ }^{1}$, Md. \\ Rahamat Ullah ${ }^{6}$, Sujan Kanti Mali ${ }^{7}$, Al Shahriar ${ }^{3}$ \\ ${ }^{1}$ Department of Fisheries Technology, Patuakhali Science and Technology University, Patuakhali - 8602, Bangladesh. \\ ${ }^{2} \mathrm{MS}$ in Aquaculture, Patuakhali Science and Technology University, Patuakhali - 8602, Mymensingh. \\ ${ }^{3}$ MS in Fisheries Technology, Bangladesh Agricultural University, Mymensingh, Bangladesh. \\ ${ }^{4}$ Department of Fisheries Biology and Genetics, Patuakhali Science and Technology University, Patuakhali - 8602, Bangladesh. \\ ${ }^{5} \mathrm{MS}$ in Agricultural Extension and Information System, Sher-E-Bangla Agricultural University, Dhaka, Bangladesh. \\ ${ }^{6} \mathrm{MS}$ in Fisheries Biology and Genetics, Patuakhali Science and Technology University, Patuakhali - 8602, Bangladesh. \\ ${ }^{7}$ Department of Biochemistry and Food Analysis, Patuakhali Science and Technology University, Patuakhali - 8602, Bangladesh.
}

\begin{tabular}{l}
\hline ARTICLE INFO \\
\hline Article history: \\
Received on: January 01, 2020 \\
Accepted on: March 02, 2020 \\
Available online: July 30, 2020 \\
\hline
\end{tabular}

Key words:

Biochemical composition, microbial load, sensory quality, skipjack tuna, frozen storage

\begin{abstract}
Skipjack tuna (Katsuwonus pelamis) belongs to the Scombridae family to determine the consistency characteristics of tuna fish loins for 28 th days at frozen $\left(-18 \pm 2^{\circ} \mathrm{C}\right)$ storage. The biochemical, microbial, and sensory quality were analyzed by association of official analytical chemists method, plate count, and Quality Index method (QIM), respectively. Protein, lipid, and moisture content were found to decrease significantly $(p<0.05)$ over the study period. Nonetheless, the values of ash, total volatile base nitrogen, tri-methyl amine nitrogen, $\mathrm{pH}$, and peroxide increased significantly $(p<0.05)$. After 28 days of frozen storage, the total bacterial load in tuna fish loins was reduced from $3.8 \times 105$ to $3.3 \times 104$ colony forming unit/g. Total coliforms reduced from 113 to 5 Most Probable Number (MPN)/g, fecal coliforms declined to undetectable level from $13 \mathrm{MPN} / \mathrm{g}$, and total Salmonella sp. also decreased from $1 \mathrm{MPN} / \mathrm{g}$ to unnoticeable, respectively. Organoleptically tuna loins were found in excellent condition up to 14th days although remained acceptable up to 28th days of the study period. The present findings should that the skipjack tuna loins can be retained under an acceptable limit for human consumption at frozen storage conditions up to 28th days.
\end{abstract}

\section{INTRODUCTION}

Nature makes fish one of the most perishable food items. The freshness of this highly perishable food item greatly affects the market acceptability [1-4]. Fish spoilage is triggered by the action of microorganisms and enzymes embedded in fish [5]. Ammonia and tri-methylamine (TMA) are developed due to these action presents in fishes, which led to the firmness and contamination in the seafood. The degree of reduction in quality relies on several factors, such as the freezing and thawing rate, storage temperature, and storage temperature fluidity [6]. Tuna is a popular fish species with much economic value relative to its increasing global market demand and is typically served fresh, canned, and frozen. There

*Corresponding Author

Suprakash Chakma, Department of Fisheries Technology, Patuakhali

Science and Technology University, Patuakhali - 8602, Bangladesh

E-mail:sup.fst@pstu.ac.bd were more than 50 species of which 5 species of tuna fishes plays an important role in European Union market [7]. Katsuwonus pelamis (skipjack tuna) is one of important pelagic fish distributed in torrid zone and warm temperate water area and also very valuable fishery species [8].

Loin from tuna fish is very delicious and can use in many kinds of seafood dishes that anybody can want but sadly, it was only available during a certain season. With the advancement of technology now fish loin product is available in any season. The buyer, however, needs the tuna loin products in fresh condition. But, the consistency measures impaired by freezing include changes in the composition of color, texture, water-retaining capacity, etc. Quicker freezing levels preserved the structural consistency and reduced the chemical reaction of several fish product forms [9-11]. That is why shelf-life studies, as well as a biochemical composition, must be needed or analyzed to 
sustaining the product or available in any season. Nevertheless, work is done on the shelf life; biochemical composition and microbiology of skipjack tuna fish loins are comparatively inadequate, especially from tropical waters. The current study was therefore undertaken for assessing the biochemical, microbiological, and sensory aspects of tuna fish loins in frozen storage condition. These values would be useful references for consumers, nutritionists, and food processors to choose the tuna fish loins, based on their appropriate uses.

\section{MATERIALS AND METHODS}

\subsection{Sample Collection and Preparation}

Freshly skipjack tuna fishes was purchased from Mohipur Fish Landing Station (Fig. 1) at Kalapara Upazila of Patuakhali District and were carried out by an insulated ice box and transported to the Fish Processing Laboratory at the Fisheries Technology Department, Patuakhali Science and Technology University, Bangladesh. The samples were washed with rinse cooled water and later by beheaded, gutted, washed, skinned, again washed, then filleted and skinless fillets were cut in the center into two pieces. Deeply dark meat is trimmed off and the tuna loins were made for analysis and samples were sealed in vacuum polyethylene bags and kept frozen at $\left(-18 \pm 2^{\circ} \mathrm{C}\right)$ until further analyses.

\subsection{Determination of Biochemical Composition}

Proximate compositions (crude protein, fat, ash, and moisture) of fish loin were analyzed in triplicate for each of sample according to the methods of Association of the Official Analytical Chemists [12]. The total volatile base nitrogen (TVB-N) and tri-methyl amine nitrogen (TMA-N) were determined according to the given methods in AMC [13]. $\mathrm{P}^{\mathrm{H}}$ and peroxide values (PV) were determined according to Eagan [14] and Wood and Aurand [15], respectively.

\subsection{Microbial Quality of Tuna Fish Loins}

About $5 \mathrm{~g}$ of samples were taken aseptically from the zipper polyethylene bag and homogenized in $195 \mathrm{ml}$ with $0.9 \% \mathrm{NaCl}$ solution. Serial dilutions of homogenates were made up to 6 or 7 dilution with triplicates and aerobic plate count (APC), Escherichia coli count (TEC), Salmonella count (TSC) and vibrio counts (TViC) were analyzed by pour plate method, using Plate Count Agar and Anumbra $100 \mathrm{~mm}$ model plate. Nutrient Agar media for APC, Eosin Methylene Blue (EMB) Agar media for TEC; Xylose Lysine Deoxyo holate (XLD) Agar media for TSC and TCBS Agar media for TViC were used, respectively, for culture. The plates were incubated at $37^{\circ} \mathrm{C}$ for $24-72$ hours on the basis of the selective media used for the specific bacterial culture. Bacterial population were counted under $\geq 30-300$ colonies per

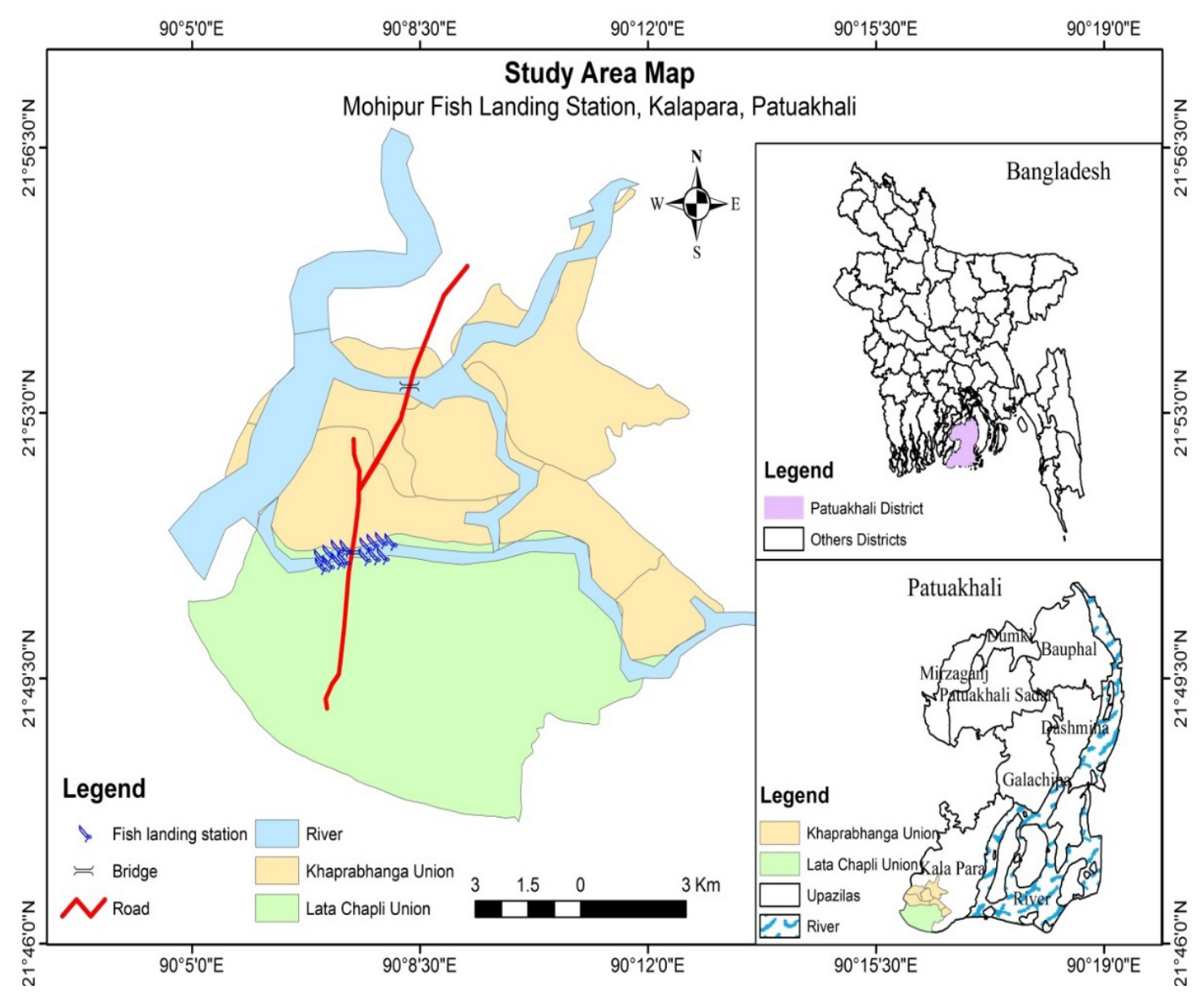

Figure 1: Map showing the collection point of the skipjack tuna fish (K. pelamis). 
plate and were indicated as colony forming unit (cfu)/g per unit (weight in g) of samples.

The APC was determined by using the formula:

APC or TPC $=\frac{\text { No. of colony } \times 10 \times \text { dilution factor } \times \text { volume of sample }}{\text { Weight of used sample }} \times 100$

\subsection{Organoleptic Study}

A testing panel evaluated the developed skipjack tuna fish loin's for the organoleptic assessment. A prepared test-scoring sheet with hedonic scales was given to the each of the individual panelist for evaluation of the products. Ten experienced panelists were selected and evaluated the organoleptic test of tuna fish loin's samples using the narrative value listed in Tables 1 and 2. All panelists were checked based on their knowledge and sensory performances on tuna loins. This performance was conducted in a room designed for sensory analysis.

Table 1. Sensory defects and defects points (DP) for assessment of quality loss of tuna fish loins.

\begin{tabular}{|c|c|c|c|c|}
\hline \multirow{2}{*}{ Characteristics } & \multirow{2}{*}{ Defects } & \multirow{2}{*}{ DP } & \multicolumn{2}{|c|}{ Tuna fish loins } \\
\hline & & & Fresh loins & Frozen loins \\
\hline \multirow[t]{4}{*}{ Odor } & a. Natural odor & 1 & & \\
\hline & b. Faint sour odor & 2 & & \\
\hline & c. Slight moderate sour odor & 3 & & \\
\hline & $\begin{array}{l}\text { d. Moderate to strong sour } \\
\text { odor }\end{array}$ & 5 & & \\
\hline \multirow[t]{4}{*}{ Color } & a. Slight pinkish red & 1 & & \\
\hline & b. Pinkish red to brownish & 2 & & \\
\hline & c. Brown to grey & 3 & & \\
\hline & d. Bleached color & 5 & & \\
\hline \multirow[t]{4}{*}{ Texture } & a. Firm, elastic & 1 & & \\
\hline & $\begin{array}{l}\text { b. Moderately soft \& some } \\
\text { loss of elasticity }\end{array}$ & 2 & & \\
\hline & c. Some softening of muscle & 3 & & \\
\hline & d. Limp or floppy & 5 & & \\
\hline \multirow[t]{6}{*}{$\begin{array}{l}\text { General } \\
\text { appearance }\end{array}$} & $\begin{array}{l}\text { a. Full bloom, bright, } \\
\text { shinning, iridescent }\end{array}$ & 1 & & \\
\hline & $\begin{array}{l}\text { b. Slight dullness, loss of } \\
\text { bloom }\end{array}$ & 2 & & \\
\hline & $\begin{array}{l}\text { c. Definite dullness and loss } \\
\text { of bloom }\end{array}$ & 3 & & \\
\hline & $\begin{array}{l}\text { d. Reddish lateral line and } \\
\text { caudal region dull, no } \\
\text { bloom }\end{array}$ & 5 & & \\
\hline & Average Defect Point (DP) & & & \\
\hline & $\begin{array}{l}\text { Grand Average Defect Point } \\
\text { (DP) }\end{array}$ & & & \\
\hline
\end{tabular}

Table 2. Grading of skipjack tuna fish loins acceptance.

\begin{tabular}{lll} 
Grade & Defects points & Degree of acceptance \\
A & Less than 2 & Excellent, Highly acceptance \\
B & 2 to less than 5 & Good/acceptable \\
C & 5 & Rejected \\
\hline
\end{tabular}

Sensory analysis is calculated by using following formula:

$$
\text { Average grade point }=\frac{\text { Number of characteristics }}{\text { Total grade point }}
$$

\subsection{Statistical Analyses}

All analysis was performed through SPSS software version 23.0 and ANOVA test was used to compare treatments. Difference between means was assessed using the Duncan at a significance level of $p<0.05$.

\section{RESULTS AND DISCUSSION}

\subsection{Biochemical Composition of Tuna Fish Loins}

Analysis of biochemical composition of tuna fish loins indicated that tuna fish loin was rich in protein $(21.54 \%)$ while lipids/fat content of tuna fish loin was $3.66 \%$ (Table 3 ). Tuna red meat is of great nutritionally comparable with white meat [16]. There were differences in protein, lipid, ash and moisture value were found in frozen storage condition $(p<0.05)$.

\subsubsection{Protein}

The protein content of frozen tuna loins was decreased $(p<0.05)$ significantly from 0 days to 28th days although no significance difference between 0th days and 7 th days. The highest protein content was recorded as $21.54 \pm 0.25 \mathrm{~g} / 100 \mathrm{~g}$ in the initial time and the lowest protein content was also recorded as $19.68 \pm 0.08 \mathrm{~g} / 100$ $\mathrm{g}$ during 28th days of storage period (Table 3). Present finding was agreement with the finding of Matsumoto et al. [17] but the study of $[16,18,19]$ revealed that skipjack tuna fish muscle protein was more than the present findings. This is an agreement with the findings of Mazorra-Manzano et al. [20] recorded that protein content of bluefin tuna fish muscle had high level of protein. The muscle protein of Bluefin tuna was more with the present findings [21]. Protein denaturation occurs due to the changes of chemical proportion and breakdown of protein. Protein denature in frozen muscle has been reviewed by several authors $[22,23]$.

\subsubsection{Lipids/fat}

Oxidation of lipid is the serious reason of deterioration in most fatty fishes. Polyunsaturated fatty acid contains in large quantity of marine fishes which is more susceptible to lipid oxidation by an autocatalytic process [24]. Gradually, oxidation of lipids creating off-flavor and reduce nutrition as well as generate other problems, such as toughness and texture [25]. The current result showed that content of fat in tuna loin was decreased significantly $(p<0.05)$ due to entire study period and ranged from $3.66 \pm 0.03 \%$ to 2.53 $\pm 0.02 \%$ (Table 3 ). This reason indicates that lipid was directly inverse relationship with the moisture $[25,26]$ revealed lipid content drastically provoked $(p<0.05)$ significantly in increasing with storage time which is contradictory with the present study. The lipid content of rainbow trout (Oncorhynchus mykiss) is increased during frozen $\left(-18 \pm 2{ }^{\circ} \mathrm{C}\right)$ storage [27]. Lipid changes occurs due to differences in period, geographical area, age, and size [28], the lipid content in tilapia fish fillets changes under 
frozen storage was consistent with descriptions presented by other authors [26].

\subsubsection{Moisture and ash content}

The content of moisture and ash of tuna loins were significantly differences $(p<0.05)$ during 28 th days $\left(-18 \pm 2{ }^{\circ} \mathrm{C}\right)$ of storage period (Table 3 ). The values of moisture was decreased significantly $(p<0.05)$ from $73.79 \pm 0.25 \%$ to $72.11 \pm 0.03 \%$ during the study period, although there is no significance $(p>0.05)$ difference between 7 th days and 14 th days (Table 3 ). A decreasing trend in the moisture was also found by Younis et al. [29]. Ash content in sea bass fillets is decrease during 60th days of frozen storage condition [26]. Thaw rigor and drip loss could be the possible reasons for decreasing in the content of moisture and ash. Moreover, moisture loss could also happen due to the desiccation and temperature fluidity in freezing process.

\subsection{4. $T V B-N$ and TMA-N}

The level of TVB-N and TMA-N value expressed that low temperature has significant $(p<0.05)$ effect on the decreasing the quality of the frozen tuna loins Figure $2 \mathrm{a}$ and $\mathrm{b}$. In the present study, the concentration of these two compounds were upward $(p<0.05)$ significantly in frozen condition where ranged from $7.89 \pm 0.05$ and $3.30 \pm 0.03$ to $13.29 \pm 0.38$ and $8.23 \pm 0.02$ $\mathrm{mg} \mathrm{N} / 100 \mathrm{~g}$, respectively. This compound in fish is generally between 5 and $20 \mathrm{mg} \mathrm{N} / 100 \mathrm{~g}$ muscle and even more this value

Table 3. Biochemical composition changes at different storage time of tuna fish loins

\begin{tabular}{lccccc} 
Parameters & \multicolumn{5}{c}{ Storage time (days) } \\
Protein & $\mathbf{0}$ & $\mathbf{7}$ & $\mathbf{1 4}$ & $\mathbf{2 1}$ & $\mathbf{2 8}$ \\
Lipid & $21.54 \pm 0.25^{\mathrm{a}}$ & $21.38 \pm 0.07^{\mathrm{a}}$ & $20.89 \pm 0.10^{\mathrm{b}}$ & $20.03 \pm 0.08^{\mathrm{c}}$ & $19.68 \pm 0.08^{\mathrm{d}}$ \\
Ash & $3.66 \pm 0.03^{\mathrm{a}}$ & $3.32 \pm 0.01^{\mathrm{b}}$ & $3.08 \pm 0.01^{\mathrm{c}}$ & $2.80 \pm 0.02^{\mathrm{d}}$ & $2.53 \pm 0.02^{\mathrm{e}}$ \\
Moisture & $2.19 \pm 0.02^{\mathrm{a}}$ & $2.89 \pm 0.02^{\mathrm{b}}$ & $3.09 \pm 0.03^{\mathrm{c}}$ & $3.81 \pm 0.03^{\mathrm{d}}$ & $4.92 \pm 0.02^{\mathrm{e}}$ \\
\hline
\end{tabular}

Values are presented as mean $\pm \mathrm{SD}$; values of a same row that do not share a same superscript are significantly different $(p<0.05)$.
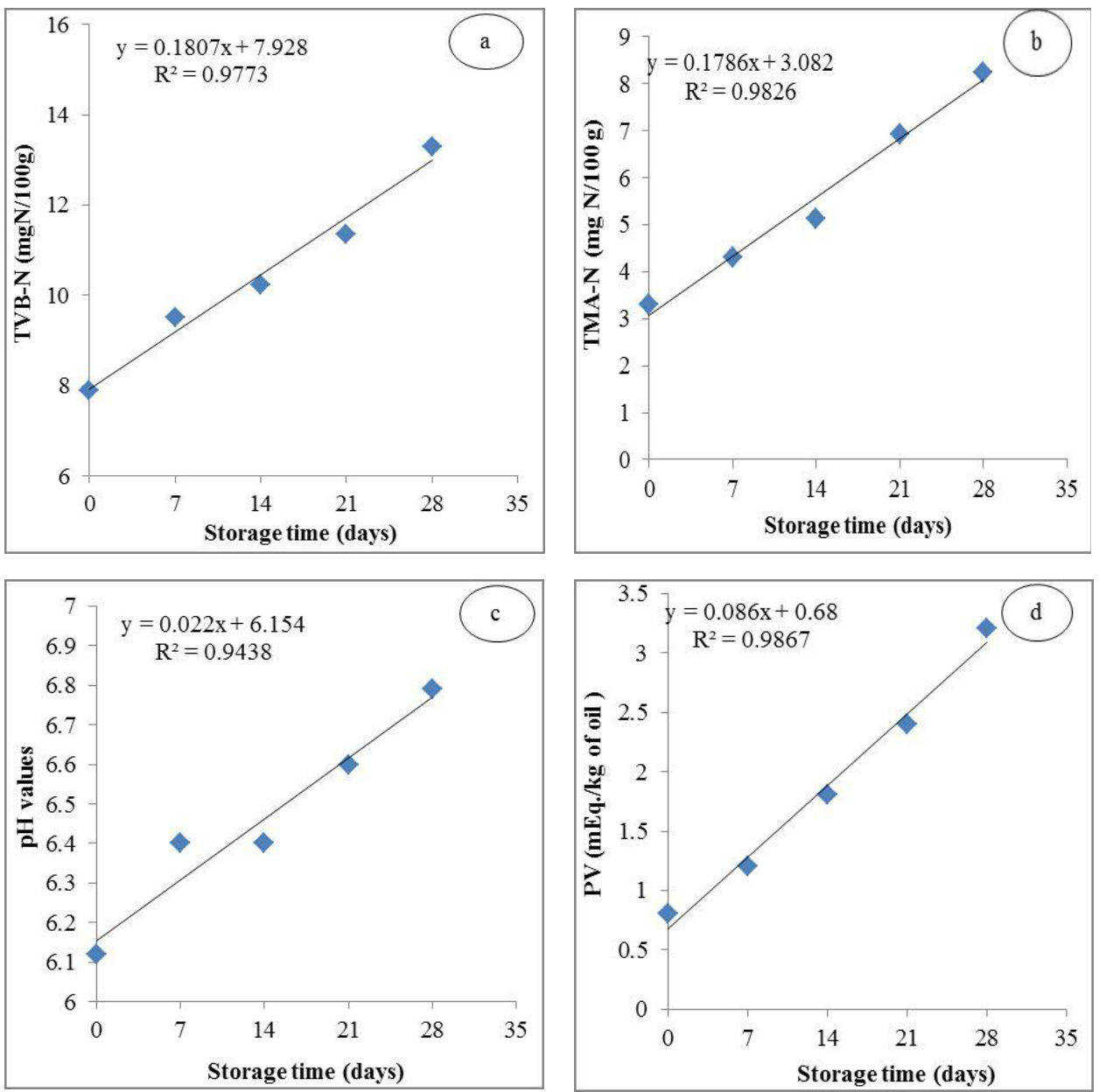

Figure 2: Correlation of TVB-N (a), TMA-N(b), $\mathrm{P}^{\mathrm{H}}(\mathrm{c})$ and $\mathrm{PV}(\mathrm{d})$ with frozen storage of tuna fish loins. 
is also happened as spoilage [14]. These two compounds in tuna loins increased progressively under frozen period but did not go across over the acceptable level for human consumption [14] until the 28th days at frozen storage. In case of most fishes, tri-methyl amine comprises mostly the volatile compounds until spoilage [30]. However, the present findings showed dissimilarities with the finding of Mazorra-Manzano et al. [20],Salah and Salouca [31], and Ben-Gigirey et al. [32], but Similar findings were reported by Xue et al. [33] for yellowtail, [34] for croaker, and [35] in iced cuttlefish. Increasing of TVB-N concentration may be ascribed to the formation of TMA, ammonia and other nitrogenous bases resulted from the deposition of TMA-N by internal enzymes [14].

\subsubsection{Peroxide and $p H$ value}

The PV showed a gradual significant increase over the whole storage time at $-18 \pm 2^{\circ} \mathrm{C}$ for skipjack tuna loins (Fig. 2c and d). However, values obtained at the end of storage period remained relatively low with the finding of Sagar et al. [36] for pink perch mince; [37] for European hake; [25] for cod and haddock. pH value for the frozen stored skipjack tuna increase progressively throughout the experiment and is generally extend up to 6.79 during 28th days of frozen state. The concentration of $\mathrm{pH}$ in fishes is usually neutral position for human consumption [38] and the level of $\mathrm{pH}$ did not cross the acceptable limit in the present finding. Increasing of $\mathrm{pH}$ is correlated with the accumulation of basic substances like ammonia and TMA [39]. Although changes of muscle $\mathrm{pH}$ in fishes under storage period are differs depend on the basis of fish species and other biological factors. Besides, the concentration of $\mathrm{pH}$ not only important parameter but can be used as a quality indicator of fishes $[38,40]$.

\subsection{Microbial Quality of Frozen Fish Loins}

Seafood product is fully depends on the sanitation condition of the water quality and the different stages of seafood processing [40]. For the determination of freshness quality of skipjack tuna loins at frozen storage, Aerobic Plate Count (APC), total coliforms, total fecal coliforms, and total Salmonella sp. were analyzed. In the current study, the original microbial load of tuna loins were observed at $3.8 \times 10^{5} \mathrm{cfu} / \mathrm{g}$, while total coliforms, fecal coliforms and Salmonella sp. represented to be 170,25, and 1 Most Probable Number (MPN)/g, respectively. Higher bacterial load in original loins might be regarded due to the ignorance of public awareness prevailing during harvesting and used contaminated knives, etc. during preparing tuna fish loins. The changes in total coliforms, fecal coliforms, and Salmonella sp. of skipjack tuna loins stored for 28th days in frozen $\left(-18 \pm 2{ }^{\circ} \mathrm{C}\right)$ condition (Fig. 3). Total bacterial load in tuna loins was decreased from 0 days to 21 th days but again started to increase on 28th day of frozen storage. Total E. coli drastically declined up to 21 th days but again increased on the 28th days of frozen period. Both the coliform bacteria gradually laid down to $1 \mathrm{MPN} / \mathrm{g}$ during 28th day of frozen state. In case of Salmonella sp. was not detected during whole present study except the initial sample of tuna fish loins. Total bacterial load decreased which might cause due to sudden cold shock under frozen state. In general, the bacterial load is increased which is

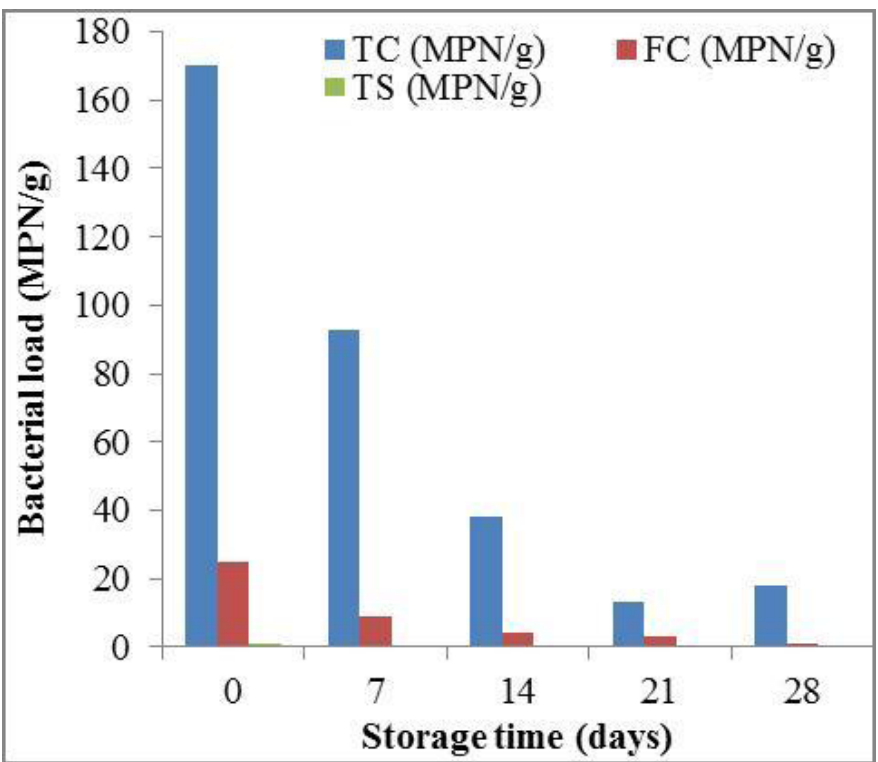

Figure 3: Microbiological quality of skipjack tuna fish loins at frozen storage $\left(-18 \pm 2^{\circ} \mathrm{C}\right)$ condition.

highly related with the increasing of time and temperature. The present finding is highly related with the study of [41]. Similar results were also reported by Thailambal [35], Sagar et al. [42], and export inspection council of India [43]. A considerable study was found by Wu et al. [44] reported that loins of skipjack tuna fish were lower than the present study. The bacterial load was similar but the total E. coli was more than the present results [45]. The frozen Nile tilapia (Oreochromis niloticus) fish fillet which contain more microbes than the present findings [46]. The total plate count raised to $7.2 \times 10^{5} \mathrm{cfu} / \mathrm{g}$ after 1 th day during $25^{\circ} \mathrm{C}$ and other dominant Enterobacteriaceae bacteria was dominant throughout the storage period [47] which is not related with the findings of the present study. In the present study, skipjack tuna loin remained considerable microbial community, which might be related to inadequate human operations during fishing and processing in the laboratory. It is recommended that microbial quality of fishes may not be surpassed $10^{6} \mathrm{cfu} / \mathrm{g}$ in fresh state which were agreement with the results of this study [48].

\subsection{Sensory Attributes of Tuna Fish Loins at Frozen Storage Condition}

The study revealed a general decline in the physical attributes, such as color, the grade reduced from A to B in the $-18 \pm 2^{\circ} \mathrm{C}$ stored samples. The grade for texture of loins varied from 1.03 \pm 0.063 to $2.58 \pm 0.24$ in the sample. While the grade for odor of the fish during ice storage showed decline from $2.48 \pm 0.20$ to $1.03 \pm 0.06$ in the sample. There was also changed in the general appearance of the loins that varied from $1.1 \pm 0.21$ to $3.21 \pm 0.43$. Statistical analysis of the four parameters assessed for organoleptic characteristics: color, texture, odor, and general appearance revealed significant differences in the organoleptic characters of the tuna loins (Table 4). The fish remained in good condition about 30 days of storage $[20,49]$ which are similar to the present study but Reza et al. [50] stated that, all fishes were being accepted not 
Table 4. Organoleptic assessment of frozen stored tuna fish loins.

\begin{tabular}{lccccc} 
Organoleptic characters & \multicolumn{5}{c}{ Storage time } \\
& $\mathbf{0}$ days & $\mathbf{7}$ days & $\mathbf{1 4}$ days & $\mathbf{2 1}$ days & $\mathbf{2 8}$ days \\
Color & $1.065 \pm 0.16^{\mathrm{a}}$ & $1.98 \pm 0.18^{\mathrm{b}}$ & $2.15 \pm 0.20^{\mathrm{c}}$ & $2.80 \pm 0.20^{\mathrm{d}}$ & $2.97 \pm 0.04^{\mathrm{e}}$ \\
Texture & $1.03 \pm 0.06^{\mathrm{a}}$ & $1.09 \pm 0.16^{\mathrm{a}}$ & $2.02 \pm 0.20^{\mathrm{b}}$ & $2.25 \pm 0.23^{\mathrm{c}}$ & $2.58 \pm 0.24^{\mathrm{d}}$ \\
Odor & $1.03 \pm 0.06^{\mathrm{a}}$ & $1.08 \pm 0.08^{\mathrm{a}}$ & $1.84 \pm 0.36^{\mathrm{b}}$ & $2.22 \pm 0.25^{\mathrm{c}}$ & $2.48 \pm 0.20^{\mathrm{d}}$ \\
General appearance & $1.10 \pm 0.21^{\mathrm{a}}$ & $2.17 \pm 0.33^{\mathrm{b}}$ & $2.40 \pm 0.39^{\mathrm{b}}$ & $3.05 \pm 0.44^{\mathrm{c}}$ & $3.21 \pm 0.43^{\mathrm{d}}$ \\
Grade & $\mathrm{A}$ & $\mathrm{A}$ & $\mathrm{A}$ & $\mathrm{B}$ & $\mathrm{B}$ \\
\hline
\end{tabular}

Values are presented as mean $\pm \mathrm{SD}$; values of a same row that do not share a same superscript are significantly different $(p<0.05)$.

more than 2 weeks under ice condition but in this study the fish loins remained edible until 28th days of storage condition.

\section{CONCLUSION}

Increasing of frozen period is directly correlated with the biochemical and microbial quality changes, which considerably accomplish to the sensory attributes of tuna loins. But the high bacterial population in primary level can be taken into consideration due to lack of personal hygiene and poor handling conditions prevailing during fishing and processing in the laboratory. However, microbial community which is linked with quality deterioration and spoilage and are associated with the increasing of proximate composition level during freezing process, representing that the stored skipjack tuna loins would be better for human consumption for up to 14 days.

\section{CONFLICT OF INTEREST}

The authors declared that they do not have any conflicts of interest.

\section{ACKNOWLEDGEMENT}

Special thanks to Fish Nutrition Lab, Bangladesh Agricultural University, Mymensingh, Bangladesh for analysis support.

\section{REFERENCES}

1. Ismail HM. The role of omega-3 fatty acids in cardiac protection: an overview - Front. Biosci 2005;10:1079-88.

2. Sikorski ZE, Kostuch S, Olley J. Protein changes in frozen fish. Crit Rev Food Sci Nutr 1976;8:97-129.

3. Shenouda SYK. Theories of protein denaturation during frozen storage of fish flesh. Adv Food Res 1980;26:275-311. doi:10.1016/ s0065-2628(08)60320-1.

4. Connel JJ. Control of fish quality. 4th edition, Fishing News Books Ltd., London, UK, 1995.

5. Arannilewa ST, Salawu SO, Sorungbe AA, Ola-Salawu BB. Effect of frozen period on the chemical, micro-biological and sensory quality of frozen tilapia fish (Sarotherodum galiaenus). Afr J Biotechnol 2005;4:852-5.

6. Giddings GG, Hill LH. Relationship of freezing preservation parameters to texture related structural damage to thermally processed crustacean muscle. J Food Proc 1978;5:249-64.

7. Hamilton A, Lewis A, McCoy MA, Havice E, Campling L. Market and industry dynamics in the global tuna supply chain. Forum Fisheries Agency Honiara (Solomon Islands). Pacific Islands Forum Fisheries Agency. Honiara, Solomon Islands, 2011.

8. Collette BB, Nauen CE. Scombrids of the world. An annotated and illustrated catalogue of tunas, mackerels, bonitos and related species known to date. FAO Fish Synop 1983:2(125):137.
9. Syamaladevi RM, Manahiloh KN, Muhunthan B, Sablani SS. Understanding the influence of state/phase transitions on ice recrystallization in Atlantic salmon (Salmo salar) during frozen storage. Food Biophys 2012;7(1):57-71.

10. Alizadeh E, Chapleau N, Lamballerie MD, Le Bail A. Effects of freezing and thawing processes on the quality of Atlantic salmon (Salmo salar) fillets. J Food Sci 2007;72(5):279-84.

11. Ayala MD, López-Albors O, Blanco A, Garcia AA, Abellan E, Ramirez ZG, et al. Structural and ultrastructural changes on muscle tissue of sea bass, Dicentrarchus labrax L., after cooking and freezing. Aquaculture. 2005;250(1-2):215-31.

12. AOAC (Association of Official Analytical Chemists). Official methods of analysis. 18th edition. Association of Official Analytical Chemists, Washington, DC, 2005.

13. AMC (Analytical Methods Committee). Recommended general methods for the examination of fish and fish products, Analyst 1979;104:434-50.

14. Eagan H, Kirk RS, Sawyer R. Pearson's chemical analysis of food. 8th edition. Churchill Livingstone, London, UK, 1981.

15. Wood AC, Aurand LW. Laboratory manual in food chemistry. Avi Publishing Co. Inc., Westport Connecticut, USA, p 22-3, 1977.

16. Mumthaz VR, Yathavamoorthi R, Anju T, Remya J, Suseela M, Gopal TKS. A comparative evaluation of the biochemical composition of three tuna species. In: Coastal fishery resources of India: conservation and sustainable utilization. p 742-53. 2010.

17. Matsumoto WM, Skillman RA, Dizon AE. Synopsis of biological data on skipjack tuna, Katsuwonus pelamis. NDAA Technical Report NMFS Circular. 1984.

18. Gopakumar K. Surimi in tropical fishery products. Oxford and IBH Publishing Co. Pvt. Ltd., New Delhi, India, p 68, 1997.

19. Nurjanah, Suseno SH, Hidayat T, Paramudhita PS, Ekawati Y, Arifanto TB. Changes in nutritional composition of skipjack (Katsuwonus pelamis) due to frying process. Int Food Res J 2015;22(5):2093-102.

20. Mazorra-Manzano MA, Pacheco-Aguilar R, Diaz-Rojas EI, LugoSanchez ME. Postmortem changes in black skipjack muscle during storage in ice. J Food Sci 2000;65(5):774-9. doi:10.1111/j.1365-2621. 2000.tb13585.x

21. Nakamura Y, Ando M, Seoka M, Kawasaki K, Tsukamasa Y. Changes of proximate and fatty acid compositions of the dorsal and ventral ordinary muscles of the full-cycle cultured Pacific bluefin tuna Thunnus orientalis with the growth. Food Chem 2007;103(1):234-41.

22. Love RM. Ice formation in frozen muscle. In: Hawthorn J and Rolfe EJ (ed.). Low temperature biology of food stuffs. Pergamon Press, Oxford, UK, pp 105-24, 1970.

23. Sikorski ZE, Kostuch S, Olley J. Protein changes in frozen fish. Crit Rev Food Sci Nutr 1976;8:97-129.

24. Smith JS, Hui YH. Food processing: principles and applications. Blackwell, Ames, IA, 2004.

25. Aubourg SP, Medina I. Influence of storage time and temperature on lipid deterioration during cod (Gadus morhua) and haddock (Melanogrammus aeglefinus) frozen storage. J Sci Food Agr 1999;79(13):1943-8. doi: 10.1002/(sici)10970010(199910)79:13<1943: aid-jsfa461>3.0.co;2-j 
26. Beklevik G, Polat A, Ozogul F. Nutritional value of sea bass (Dicentrarchus labrax) fillets during frozen (-18C) storage. Turk J Vet Anim Sci 2005;29(3):891-5.

27. Tokur B. The quality changes of trout fillets (Oncorhynchus mykiss) with vegetable sauce during frozen storage. $\mathrm{PhD}$ Thesis, Ege University of Natural Science, Institute of Üzmir, Izmir, Turkey, 2000.

28. Falch E, Rustadb T, Jonsdottirc R, Shawd NB, Dumaye J, Bergee JP, et al. Geographical and seasonal differences in lipid composition and relative weight of by-products from gadiform species. J Food Compos Anal 2006;19:727-36.

29. Younis EM, Al-Asgah NA, Abdel-Warith, AWA, Al-Mutairi AA. Seasonal variations in the body composition and bioaccumulation of heavy metals in Nile tilapia collected from drainage canals in Al-Ahsa, Saudi Arabia. Saudi J Biol Sci 2015;22(4):443-7. doi: 10.1016/j. sjbs.2014.11.020

30. Martinsdottir E, Magnusson H. Keeping quality of sea-frozen thawed cod fillets on icecap. J Food Sci 2001;66:1403-5.

31. Salah S, Salouca S. The effect of natural antioxidant (Thymus vulgaris Linnaeus) on flesh quality of tuna (Thunnus thynnus (Linnaeus)) during chilled storage. Pan-Am J Aquatic Sci 2008;3(1):36-45.

32. Ben-Gigirey B, Baptista DSJMV, Villa TG, Barros-Velazquez J. Chemical changes and visual appearance of albacore tuna as related to frozen storage. J Food Sci 1999;64:20-4.

33. Xue C, Ye M, Li Z, Cai Y, Tan L, Lin H, et al. Changes in the volatile compounds of yellowtail (Seriola aureovitata) during refrigerated storage. Asian Fish Sci 2000;13:263-70.

34. Joseph BO, Adnes EO. Storage life of croaker (Pseudotholitus senegalensis) in ice and ambient temperature. Afri J Biomed Res 2004;7:3-17.

35. Thailambal AS. Effect of processing on bacterial population of cuttlefish and crab and determination of bacterial spoilage and rancidity developing on frozen storage. J Food Proc Pres 2007;31: 13-31.

36. Sagar RGV, Srikar LN, Sudhakara NS. Deteriorative changes in pink perch mince during frozen storage. Int J Food Sci Tech 2007;27(3):271-6. doi:10.1111/j.1365-2621. 1992.tb02028.x

37. Pérez-Villarreal B, Howgate P. Deterioration of European hake (Merluccius merluccius) during frozen storage. J Sci Food Agr 1991;55(3):455-69. doi:10.1002/jsfa.2740550313

38. Ruiz-Capillas C, Moral A. Correlation between biochemical and sensory quality indices in hake stored in ice. Food Res Int 2001;34(5):441-7. doi:10.1016/s0963-9969(00)00189-7

39. Hebard CE, Flick GJ, Martin RE. Occurrence and significance of trimethylamine oxide and its derivatives in fish and shellfish. In Chemistry and Biochemistry of Marine Food Products Martin, AVI Publishing, Westport, UK, pp 149-75, 1982.
40. Huss HH. Fresh fish quality and quality changes. FAO Fisheries Series, No. 29, FAO, Rome, Italy. 1988.

41. Alam NSM, Golam M, Bhuiyan DH. Prevalence of bacteria in the muscle of shrimp in processing plant. Internet J Food Safe. 2004;5: 21-23.

42. Murthy LN, Rao BM, Prasad MM. Biochemical and microbiological evaluation of tuna loin processing waste. Fish Tech 2012;49:45-49.

43. EIC (Export Inspection Council of India). Quality assurance and monitoring system manual on export of fresh, frozen processed fish and fishery products. Export Inspection Council of India, Ministry of Commerce, GOI, New Delhi, India, 1995.

44. Wu X, Su YC. Effects of frozen storage on survival of Staphylococcus aureus and enterotoxin production in precooked tuna meat. J Food Sci 2014;79:1554-9.

45. Casalinuovo F, Brindisi D, Rippa P, Ceniti C, Ciambrone L, Musarella R, et al. Microbiological quality and safety of skipjack tuna loins (Katsuwonus pelamis) intented for canning. Maced Vet Rev 2018;41(1):33-7.

46. Emire SA, Gebremariam MM. Influence of frozen period on the proximate composition and microbiological quality of Nile tilapia fish (Oreochromis niloticus). J Food Process Pres 2010;34:743-57.

47. Tahmouzi S, Ghasemlou M, Aliabadi FS, Shahraz F, Hosseini H, Khaksar R. Histamine formation and bacteriological quality in skipjack tuna (Katsuwonus pelamis): Effect of defrosting temperature. J Food Process Pres 2012;37(4):306-13.

48. ICMSF (International Commission on Microbiological Specifications for Foods). Microorganisms in foods, 6: microbial ecology of food commodities. Blackie Academic and Professional, Baltimore, MD, pp 174-235, 1998

49. Kamal M, Islam MA, Mansur MN, Hossain MA, Bhuiyan MAI Biochemical and sensory evaluation of hilsa fish (Hilsa ilisha) during frozen storage. Indian J Mar Sci 1996;25:320-3.

50. Reza MS, Bapary MAJ, Ahasan CT, Islam MN, Kamal M. Shelf life of several marine fish species of Bangladesh during ice storage. Int J Food Sci Tech 2009;44:1485-94.

How to cite this article:

Chakma S, Saha S, Hossain N, Rahman MA, Akter M, Hoque MS, Ullah MR, Mali SK, Shahriar A. Biochemical, microbial, and sensory attributes of skipjack tuna (Katsuwonus pelamis) fish loins at frozen storage condition. J Appl Biol Biotech 2020;8(04):058-064. DOI: 10.7324/JABB.2020.80409 